This is a self-archived version of an original article. This version may differ from the original in pagination and typographic details.

Author(s): Mironova, Ekaterina; Gopko, Mikhail; Pasternak, Anna; Mikheev, Viktor;

Title: Trematode cercariae as prey for zooplankton : effect on fitness traits of predators

Year: 2019

Version: Submitted version (Preprint)

Copyright: @ Cambridge University Press 2018

Rights: In Copyright

Rights url: http://rightsstatements.org/page/InC/1.0/?language=en

Please cite the original version:

Mironova, E., Gopko, M., Pasternak, A., Mikheev, V., \& Taskinen, J. (2019). Trematode cercariae as prey for zooplankton : effect on fitness traits of predators. Parasitology, 146(1), 105-111. https://doi.org/10.1017/\$0031182018000963 


\section{Trematode cercariae as prey for zooplankton: effect on fitness traits of predators}

Short running title: "Removal of trematode larvae by zooplankters"

Mironova Ekaterina ${ }^{\mathrm{a}}$, Gopko Mikhail ${ }^{\mathrm{a}}$, Pasternak Anna ${ }^{\mathrm{b}}$, Mikheev Viktor ${ }^{\mathrm{a}}$, Taskinen $\mathrm{J}^{\mathrm{c}}$.

Ekaterina Mironova (corresponding author)

${ }^{a}$ A.N. Severtsov Institute of Ecology and Evolution, Russian Academy of Sciences

Leninskij prosp., 33, 119071 Moscow, Russia

Phone: +7 (495) 959 9725, fax: +7 (499) 9521501

E-mail: katya_mironova@mail.ru

Mikhail Gopko, Viktor Mikheev

${ }^{a}$ A.N. Severtsov Institute of Ecology and Evolution, Russian Academy of Sciences

Leninskij prosp., 33, 119071 Moscow, Russia

\section{Anna Pasternak}

${ }^{\mathrm{b}}$ Shirshov Institute of Oceanology, Russian Academy of Sciences

Nahimovskiy prosp., 36, 117997 Moscow, Russia

Jouni Taskinen

${ }^{\mathrm{c}}$ University of Jyväskylä

Department of Biological and Environmental Science P.O. Box 35, FIN-40014 Finland 


\section{SUMMARY}

Removal of parasite free-living stages by predators has previously been suggested an important factor controlling parasite transmission in aquatic habitats. Experimental studies of zooplankton predation on macroparasite larvae are, however, scarce.

We tested whether trematode cercariae, which are often numerous in shallow waters, are suitable prey for syntopic zooplankters. Feeding rates and survival of freshwater cyclopoids (Megacyclops viridis, Macrocyclops distinctus), calanoids (Arctodiaptomus paulseni), cladocerans (Sida crystallina) and rotifers Asplanchna spp., fed with cercariae of Diplostomum pseudospathaceum, a common fish trematode, were studied. In additional longterm experiments, we studied reproduction of cyclopoids fed with cercariae.

All tested zooplankton species consumed cercariae. The highest feeding rates were observed for cyclopoids ( $33 \pm 12$ cercariae ind $^{-1} \mathrm{~h}^{-1}$ ), which actively reproduced (up to one egg clutch day $^{-1}$ ) when fed ad libitum with cercariae. Their reproductive characteristics did not change significantly with time, indicating that cercariae supported cyclopoids' dietary needs. Mortality of rotifers and cladocerans was high (25-28\% individuals) when exposed to cercariae in contrast to cyclopoids and calanoids $(<2 \%)$. Cercariae clogged the filtration apparatus of cladocerans and caused internal injuries in predatory rotifers, which ingested cercariae.

Observed trophic links between common freshwater zooplankters and cercariae may significantly influence food webs and parasite transmission in lentic ecosystems.

Keywords: Diplostomum, eye fluke, parasite transmission, freshwater ecosystem, food web, reproduction, mortality, cladocerans, copepods, rotifers. 


\section{INTRODUCTION}

Though parasites may constitute a substantial part of total biodiversity and biomass in aquatic ecosystems (Hudson et al. 2006; Kuris et al. 2008; Preston et al. 2013), they are traditionally ignored when studying food-webs. In the last decades, it has been shown that parasite-predator links are very abundant (36-44\% of observed trophic links) in aquatic food webs (Lafferty et al. 2006; Amundsen et al. 2009). A large share of these links is formed by the concomitant predation, when parasites are consumed together with their hosts (Johnson et al. 2010). However, direct feeding on parasite free-living stages is also common in aquatic ecosystems (Lafferty et al. 2008; Morley, 2012). Thus, almost all groups of benthic organisms (e.g. carnivorous plants, cnidarians, turbellarians, oligochaetes, bryozoans, mollusks, crustaceans, insect larvae, fishes) were reported to consume free-living stages of parasites (reviewed in Thieltges et al. 2008a; Johnson et al. 2010; Orlofske et al. 2015; Gopko et al. 2017a).

The role of zooplankters as predators of parasites is much less studied. Many zooplankters feed on nano- and microparticles and were found to effectively clean water of various pathogenic bacteria (Escherichia coli, fecal coliforms, streptococci), cysts of parasitic protists (Giardia) and zoospores of amphibian chytrid fungus (reviewed in Jasper et al. 2013; Buck et al. 2011; Hamilton et al. 2012; Schmeller et al. 2014). Some zooplankters (copepods) were reported to consume macroparasites and vectors, for example, juvenile nematodes (Achinelly et al. 2003) and mosquito larvae (reviewed in Marten and Reid, 2007).

The information about predation of zooplankton on trematode free-living stages (miracidia and cercariae) is still scarce though trematode larvae, especially cercariae, are often numerous in plankton (Morley, 2012). The abundance of cercariae can reach up to 300 ind. $\mathrm{L}^{-1}$ in still freshwater habitats (Morley, 2012) and their annual production in estuaries can constitute $10-43 \mathrm{~kg} \mathrm{ha}^{-1} \mathrm{y}^{-1}$ (Kuris et al. 2008). On average, a single infected Lymnaea stagnalis snail can release more than 37,000 cercariae of the present study species, Diplostomum pseudospathaceum, daily (Karvonen et al. 2004a). The smallest trematode freeliving stages are less than $200 \mu \mathrm{m}$ in size and therefore can serve as prey for many planktonic crustaceans (e.g. raptorial cyclopoids and cladocerans), which are voracious predators of similar-sized motile food objects (Cummins et al. 1969; Kerfoot, 1977; Brandl, 1998).

However, to our knowledge, there is only one study (Christensen et al. 1977) on feeding of zooplankton (Daphnia pulex) on miracidia (the first free-living stage of trematodes) and just a few focused on consumption of cercariae (Tokobaev et al. 1979; 
Christensen, 1979; Christensen et al. 1980; Intapan et al. 1992; Schotthoefer et al. 2007). For instance, cercariae of different trematode species are ingested by the predatory rotifer (Eosphora ehrenbergi) (Tokobaev et al. 1979). Reported estimates of consumption of cercariae by planktonic crustaceans vary from a considerable effect (Christensen, 1979; Christensen et al. 1980; Intapan et al. 1992) to the absence of a feeding response (Schotthoefer et al. 2007). Moreover, the influence of cercarial prey on the fitness traits of predators is still unknown. Cercariae contain glycogen and lipid stocks (Thieltges et al. 2008b; Morley, 2012) that make them suitable food for zooplankters. In still waters, dense "clouds" of cercariae are formed around infected freshwater snails and mussels, (Lyholt and Buchmann, 1996; Taskinen, 1998; Karvonen et al. 2004a; Morley, 2012), the typical first intermediate hosts of trematodes. Such cercarial aggregations could be easily detected and consumed by planktonic predators living in the same shallow water habitats, especially by selective-feeders, which effectively search the attractive prey.

The key role of zooplankton in aquatic food webs and high biomass and nutritional value of trematode cercariae (Thieltges et al. 2008b; Preston et al. 2013) suggest that these trophic links could be important. Removal of free-living stages of parasites by predators can strongly reduce parasite transmission in aquatic ecosystems resulting in decreased infection intensities and prevalences in host organisms (Schotthoefer et al. 2007; Orlofske et al. 2012; Gopko et al. 2017a).

The present study aims to assess the role of trematode cercariae as a food source for syntopic (sharing the habitat with molluscs producing cercariae) zooplankton organisms. We experimentally tested (1) the ability of rotifers, cladocerans and copepods to consume cercariae of the common fish trematode (eye fluke, Diplostomum pseudospathaceum) and (2) the effect of cercarial diet on the fitness-related traits of planktonic predators. Our hypotheses were (1) that certain freshwater zooplankters can consume/eliminate trematode cercariae, and (2) that cercariae can serve as nutritious food objects, supporting their growth and reproduction.

\section{MATERIALS AND METHODS}

$\underline{\text { Study objects }}$

Experiments were conducted at the Konnevesi research station (University of Jyväskylä, Finland) in summer 2016. We used cercariae of the eye fluke $D$. 
pseudospathaceum for our study, because this parasite is very common in lymnetic systems of temperate and boreal zones and can hamper fish farming (Shigin, 1980; Karvonen et al. 2006). D. pseudospathaceum infects mollusks (first intermediate host), many fishes (second intermediate host) and fish-eating birds (definitive host) (Valtonen and Gibson, 1997; Karvonen et al. 2006). It decreases host fitness by reducing vision in fish (Owen et al. 1993; Karvonen et al. 2004b) and manipulates host behaviour to increase parasite transmission (Seppälä et al. 2004; Mikheev et al. 2010; Gopko et al. 2015, 2017b). In addition, cercariae of $D$. pseudospathaceum have different size, morphology and behaviour than most that have been used in previous feeding experimental studies (Tokobaev et al. 1979; Christensen, 1979; Christensen et al. 1980; Intapan et al. 1992; Schotthoefer et al. 2007).

Cercariae of D. pseudospathaceum were obtained from the infected pond snails Lymnaea stagnalis collected from the shallow nearshore habitats of Lake Konnevesi. Between the experiments snails were stored in the dark at $4^{\circ} \mathrm{C}$. To induce cercariae shedding, they were placed under bright light at $18^{\circ} \mathrm{C}$ for 2 hours before each experiment. Zooplankton was collected from the same site (depth 0.5-3 m) as snails. Copepods and cladocerans were collected with a plastic bucket (to avoid their damage) and rotifers with a small Epstein plankton net (70- $\mu \mathrm{m}$ mesh). In the laboratory, we picked out individuals of several common planktonic species with a pipette (rotifers Asplanchna spp., cyclopoids Megacyclops viridis, Macrocyclops distinctus, calanoids Arctodiaptomus paulseni, cladocerans Sida crystallina). Before the experiments, zooplankters were acclimated to the laboratory conditions $\left(18^{\circ} \mathrm{C}\right.$, 20:4 L:D light) in 250-mL beakers filled with filtered $(50-\mu \mathrm{m}$ mesh) lake water containing natural microplankton for 24-48 hours. All zooplankters tested in each experiment were from the same sample.

\section{$\underline{\text { Short-term feeding experiments }}$}

The consumption of trematode cercariae (D. pseudospathaceum) by the predators (Asplanchna spp., M. distinctus, M. viridis, A. paulseni, S. crystallina) was assessed in incubation experiments which lasted for $5 \mathrm{~h}$ (Table 1). Since prey removal is often higher in the first hours of incubation (Conover, 1978) we additionally estimated grazing effect after the first two hours of 5-h incubation experiments and in separate feeding experiments lasted for two hours (only with copepods, which fed most intensively). Two species of cyclopoids (M. distinctus, $M$. viridis) were tested together, because it was not possible to identify them to the species level before fixation in the end of the experiment. The number of M. distinctus 
was about twice that of $M$. viridis. Experiments with each planktonic predator were repeated twice on different dates, except for S. crystallina (only one experiment was conducted).

In predation treatments, zooplankters were placed in the beakers with $100 \mathrm{~mL}$ of filtered (pore size $1 \mu \mathrm{m}$ ) lake water and acclimated without food for 4-7 h. Each beaker contained 10-19 crustaceans or 35-40 rotifers depending on the experiment (Table 1). Control treatments (without zooplankters) were used to assess changes in cercariae numbers unrelated to predation. There were 5 control and 5 'predation' treatment replicates in all experiments. The only exception was one of the experiments with Asplanchna spp. where there were only three 'predation' replicates.

Cercariae of D. pseudospathaceum freshly produced (in two hours before the experiment) from 4-5 snails were mixed and added in equal volume (20-25 mL) to all replicates in control and predation treatments. The age of cercariae was less than two hours at the beginning of experiments and no more than four or seven hours at the end (depending on incubation time). Mean initial concentration of cercariae in different experiments varied from 6 to 28 cercariae $\mathrm{mL}^{-1}$ (Table 1). Such high concentrations of cercariae were used to simulate natural density of cercariae in the vicinity of infected snails (Morley, 2012). We estimated the concentration of cercariae at the start/end of the incubation (in case of copepods also after the first two hours of 5-h incubation) from three 2-mL samples taken from the each beaker after gentle mixing. Averages from these three samples were used in the subsequent statistical analysis. Cercariae were counted in a Bogorov zooplankton counting chamber under a dissecting microscope ( $28 \times$ magnification) within two hours after sampling to avoid decrease in cercariae number due to the natural mortality. The effect of predation was evaluated by the comparison of changes in cercariae numbers in control/predation treatments at the beginning and the end of the experiment using repeated-measures ANOVA. Clearance and ingestion rates were calculated according to Frost (1982) and Conover (1978).

Mortality of zooplankters used in the experiments was assessed at the end of the incubation. Planktonic crustaceans were measured after fixation with buffered formaldehyde (2\% final concentration), while rotifers were measured in vivo (Table 1). Sizes of $D$. pseudospathaceum cercariae (body length with furca) were also measured in vivo and varied from 375 to $550 \mu \mathrm{m}($ mean $\pm \mathrm{SD}=454 \pm 60 \mu \mathrm{m}, \mathrm{N}=50)$.

Testing the effect of cercariae on fitness traits of predators 
Cyclopoids M. distinctus and M. viridis

Since M. distinctus and M. viridis demonstrated low mortality and significant removal of cercariae in incubation experiments they were chosen as objects for the additional longterm experiments. In the experiments we tested how feeding on cercariae during 9-17 days affects the survival and reproduction in these cyclopoids. We used adult $M$. distinctus and $M$. viridis females (18 and 11 ind. respectively, identified at the end of the experiment). All females were at the similar spawning stage (after formation of egg clutches). In order to achieve this, females with egg clutches were sorted from the stock culture. After hatching of nauplii and formation of the next egg clutch these females were placed individually in beakers with $50 \mathrm{~mL}$ of filtered (pore size $1 \mu \mathrm{m}$ ) lake water and used in the experiment. They were maintained at $18^{\circ} \mathrm{C}, 20: 4 \mathrm{~L}: \mathrm{D}$ light and fed only with the D. pseudospathaceum cercariae. Concentrations of cercariae varied from 8 to 13 cercariae $\mathrm{mL}^{-1}$ (average $\pm \mathrm{SD}=9 \pm 3$ ) from day to day, but were similar in all beakers each day. Cercariae were produced every day by several (4-5) infected L. stagnalis snails placed in filtered (pore size $1 \mu \mathrm{m}$ ) water for 2 hours. Before the addition of fresh cercariae, the water from each experimental beaker was removed by the pipette after gentle mixing (about $10 \mathrm{~mL}$ was left) and replenished by fresh food medium to restore the initial water volume. Each female was checked twice a day to monitor survival, egg formation and hatching. Numbers of hatched nauplii were counted by inspecting the whole water volume $(50 \mathrm{~mL})$ in a Bogorov chamber. To avoid cannibalism, the females were separated from nauplii immediately after hatching and placed in new beakers with cercariae. The nauplii hatched from the first clutch were not counted since their number can be more strongly affected by the female feeding before the start of experiment than by experimental feeding conditions. The durations of clutch periods (= embryonic development time, from egg clutch emergence to nauplii hatching) and interclutch periods (time between two clutches) were calculated for each female throughout the experiment. At the end of experiments all females were preserved with the formaldehyde solution ( $2 \%$ final concentration) for species idenification and measurements of prosome length).

The STATISTICA 10 (StatSoft Inc., 2011) and R software was used for statistical analysis (R Core Team, 2017). To compare coefficients of variation (CV) of clutch and interclutch periods in $M$. distinctus and $M$. viridis, we used an asymptotic test for the equality of coefficients of variation from k populations' (Feltz and Miller, 1996) from the 'cvequality' R package (Marwick and Krishnamoorthy, 2016). The 'ggplot2' package (Wickham, 2010) 
was used for graphical presentation of the data.

\section{Rotifers Asplanchna spp.}

Since microscopical observations of rotifers Asplanchna spp. at the end of the grazing experiments indicated that some large individuals ingested cercariae and then died we asked if cercariae can influence size structure of populations of this predatory rotifer. To answer this question we measured sizes of rotifers, which survived after exposure with cercariae (mean initial concentration $18 \pm 1$ cercariae $\mathrm{mL}^{-1}$ ) in the grazing experiment (38 ind., 5 beakers) and rotifers of the control group (54 ind., 5 beakers), exposed in filtered (pore size 1 $\mu \mathrm{m})$ lake water without cercariae. Measurements were done in vivo (in the stretched state) under the microscope and then mean sizes were compared using t-test. The rotifers of the both groups were from the same sample and acclimated and exposed (during $24 \mathrm{~h}$ ) in similar conditions, but the control group was tested a day later (after the end of grazing experiment). Although the mean size of rotifers was not estimated at the beginning of the grazing experiment we supposed that it did not differ from the mean size of rotifers in the control group.

\section{RESULTS}

\section{Zooplankton feeding on cercariae}

Cyclopoids $M$. distinctus, $M$. viridis and cladocerans $S$. crystallina significantly reduced the number of cercariae during all incubation experiments, i.e. time*treatment interaction was significant $(P<0.05$ in all cases, Table 1 , Supplementary Table S1). The effects of other tested zooplankters on cercariae numbers were significant only in some of experiments. Rotifers Asplanchna spp. did not affect cercariae abundance in one experiment but showed a significant reduction effect $(P=0.009$, Table 1 , Supplementary Table S1) in another one. Calanoids A. paulseni removed cercariae $(P=0.028)$ in the first two hours of one experiment, but their effect was not significant during the next $3 \mathrm{~h}$ of incubation and in the second experiment (Table 1, Supplementary Table S1).

The highest rates of the cercariae removal were observed for cyclopoids (mix of $M$. distinctus and $M$. viridis), which caused on average 5-fold decrease in cercariae numbers in 5 
h when compared with control (Table 1). The removal of cercariae by the cladocerans $S$. crystallina was less pronounced (average 2-fold decrease in $5 \mathrm{~h}$ ), though the number of cladocerans in experimental beakers were slightly higher than that of cyclopoids (Table 1). Individual clearance rates constituted 1.5-3.6 (mean $\pm \mathrm{SD}=2.6 \pm 0.8) \mathrm{mL} \mathrm{ind}^{-1} \mathrm{~h}^{-1}$ for cyclopoids and 1.3-3.2 (mean $\pm \mathrm{SD}=2.2 \pm 0.9) \mathrm{mL} \mathrm{ind}^{-1} \mathrm{~h}^{-1}$ for S. crystallina. However, predation was discontinuous, thus the estimation of hourly clearance and ingestion rates is only approximate. Calanoids and cyclopoids (M. distinctus and M. viridis together) removed cercariae mainly during the first two hours of incubation (on average $64-74 \%$ of all removed by cyclopoids cercariae). Therefore, clearance rates of cyclopoids calculated for this period (up to $4.8 \mathrm{~mL} \mathrm{ind}^{-1} \mathrm{~h}^{-1}$, mean $\pm \mathrm{SD}=2.9 \pm 1.2$ ) were higher than rates obtained for whole $5 \mathrm{~h}$ period. The ingestion rates of cyclopoids also were the highest when calculated for $2 \mathrm{~h}$ period $\left(\right.$ mean $\pm \mathrm{SD}=33 \pm 12$ cercariae ind $^{-1} \mathrm{~h}^{-1}$ ), but were lower and similar to the mean ingestion rates of $S$. crystallina $\left(14 \pm 3\right.$ cercariae ind $\left.^{-1} \mathrm{~h}^{-1}\right)$ when calculated for $5 \mathrm{~h}$ period.

\section{$\underline{\text { Effect of cercarial prey on zooplankton fitness traits }}$}

Consumption of cercariae affected their planktonic predators in different ways, e.g., supported reproduction of some species (cyclopoids $M$. distinctus and $M$. viridis) but increased mortality of other (rotifers Asplanchna spp., cladocerans S. crystallina). Microscopic observations of rotifers Asplanchna spp. at the end of the feeding experiments showed that some large individuals ingested 1-3 cercariae (Fig. 1) and died in the next 6 hours. The mortality of rotifers exposed to cercariae $(28 \%$ of total number in $6 \mathrm{~h})$ was significantly higher (Fisher's exact test, $P<0.001)$ than in the control group $(<3 \%)$. The additional experiment $(24 \mathrm{~h})$ showed that incubation with cercariae changed the size distribution of rotifers. The mean $( \pm \mathrm{SD})$ size of rotifers was significantly lower in withcercariae treatment $\left(t\right.$-test, $\left.t_{90}=-3.96, P=0.033\right)$ than in the control group $(1.3 \pm 0.3 \mathrm{~mm}, N=$ 38 and $1 \pm 0.2 \mathrm{~mm}, N=54$, respectively). In addition, at the end of experiment, large rotifers ( $>1.4 \mathrm{~mm}$ in size) constituted $13 \%$ of total abundance in the group with cercariae, while in the control group the share of this size class was 39\%. It was not possible to obtain data about sizes of rotifers at the start of experiment, but we suggest that size structure of both groups was similar, since they were randomly selected from the single plankton sample and maintained in similar conditions before the experiment. This difference in the size structure was possibly caused by the decrease in numbers of the largest rotifers $(>1.4 \mathrm{~mm}$ in size), which ingested cercariae and were damaged by them as microscopic observations suggested. 
Cercariae kept moving inside the rotifers for a while after being ingested, often causing internal injuries of predator by cercarial furcae. Small rotifers were not observed ingesting cercariae.

The mortality of cladocerans $S$. crystallina incubated with cercariae during $5 \mathrm{~h}$ was also high ( $25 \%$ of initial number). Microscopic examination of the dead individuals showed that parts of cercariae clogged the filtration apparatus of the cladocerans. However, mortality of copepods (cyclopoids $M$. distinctus, M. viridis and calanoids A. paulseni) incubated with cercariae was low $(<2 \%)$ and did not differ from the control vessels $(P<0.001$ in all cases $)$.

Long-term experiments showed that cyclopoids $M$. distinctus and $M$. viridis successfully reproduced when fed with the cercarial monodiet. Many of the females $(45 \%$ and 39\% for M. viridis and M. distinctus, respectively) produced up to four egg clutches in 17 days (Fig. 2, Supplementary Table S2). The duration of the whole cycle (from clutch emergence to emergence of the next clutch) and numbers of nauplii hatched from one clutch did not change significantly with time for both species (ANOVA, $P=0.85, P=0.39$ for $M$. distinctus, $P=0.88, P=0.06$ for $M$. viridis, respectively, Supplementary Table S2). Numbers of nauplii were significantly higher $\left(t\right.$-test, $\left.t_{51}=-8.67, P<0.001\right)$ in $M$. viridis (53160 , mean $\pm \mathrm{SD}=89 \pm 22$ nauplii, $N=20)$, than in $M$. distinctus females $(19-69$, mean $\pm \mathrm{SD}=$ $46 \pm 13$ nauplii, $N=33$ ), which were smaller in size (mean $\pm \mathrm{SD}=1258 \pm 139$ and $1132 \pm 70 \mu \mathrm{m}$, respectively). The larger cyclopoid species ( $M$. viridis) had a longer interclutch period $($ mean $\pm \mathrm{SD}=50 \pm 22 \mathrm{~h})$, than smaller $M$. distinctus $($ mean $\pm \mathrm{SD}=24 \pm 23 \mathrm{~h})\left(t\right.$-test, $t_{64}=-4.44, P$ $<0.001)$, but had a shorter clutch period (mean $\pm \mathrm{SD}=55 \pm 9$ and $74 \pm 42 \mathrm{~h}$, respectively) ( $t$-test, $\left.t_{68}=2.27, P=0.026\right)$. As a result, the duration of whole cycle did not differ between these species $(P=0.75)$ and constituted $24-259 \mathrm{~h}($ mean $\pm \mathrm{SD}=97 \pm 5 \mathrm{~h})$ and $72-144 \mathrm{~h}($ mean $\pm \mathrm{SD}=$

$102 \pm 3 \mathrm{~h}$ ) for $M$. distinctus and $M$. viridis, respectively. In both species, the duration of interclutch period was more variable $(C V=0.959$ for $M$. distinctus, $C V=0.437$ for $M$. viridis) than duration of the clutch period ( $C V=0.562$ for $M$. distinctus, $C V=0.167$ for $M$. viridis) (Fig. 2, Supplementary Table S2). These parameters were more variable in the smaller M. distinctus.

\section{DISCUSSION}

The results obtained indicated that not only benthic (reviewed in Johnson et al. 2010), 
but also planktonic organisms could prey on free-living stages of trematodes. Consumption of cercariae by zooplankters was detected previously using radioisotope methods (Christensen, 1979; Christensen et al. 1980), but direct evidences obtained in feeding experiment are still scarce and provide controversial information (Tokobaev et al. 1979; Intapan et al. 1992; Schotthoefer et al. 2007). Thus, some species of cladocerans (S. crystallina, Daphnia pulex, D. longispina), rotifers (Eosphora ehrenbergi) and cyclopoids (Cyclops strenuous, Mesocyclops leuckarti) have been reported to remove cercariae of different trematodes (Schistosoma mansoni, Opisthorchis viverrini, Plagiorchis sp., etc.) less than $0.5 \mathrm{~mm}$ in size (Tokobaev et al. 1979; Christensen, 1979; Christensen et al. 1980; Intapan et al. 1992), but did not consume or demonstrated only low predation when fed with larger (about $1 \mathrm{~mm}$, Orlofske et al. 2015) Ribeiroia ondatrae cercariae (Schotthoefer et al. 2007). In our feeding experiments we used cercariae of $D$. pseudospathaceum, which are differed by size (about $450 \mu \mathrm{m}$ in size) and morphology from cercariae that have been investigated previously, however the swimming behaviour of D. pseudospathaceum (intermittent with positive phototactic orientation) is similar to some of these species (e.g. S. mansoni, O. viverrini) (Haas et al. 1990; Haas, 1992). Our results indicated that several common freshwater planktonic organisms (cyclopoids M. distinctus, M. viridis, calanoids Arctodiaptomus paulseni, cladocerans $S$. crystallina, predatory rotifers Asplancna spp.) can consume cercariae of the trematode D. pseudospathaceum, which are often numerous in the nearshore lentic waters (Morley, 2012). Removal of cercariae was the highest in cyclopoids, lower in cladocerans and minimal in calanoids and rotifers.

To our knowledge, this is the first study focused on the effect of cercarial prey on the fitness-related traits of their predators. Many food objects ingested by zooplankters (e.g. cyanobacteria, green algae, some dinoflagellates) are toxic or nutritionally poor, and can suppress the growth, fecundity and predator-avoidance behaviour of the consumers (Bernardi and Giussani, 1990; Koski et al. 1998; Turner, 2014; Lasley-Rasher et al. 2016). The obtained results showed that the removal of cercariae by zooplankters does not necessarily mean their successful digestion, but can lead to increased mortality of predators. Cercariae are likely to clog the filtration apparatus of cladocerans and cause heavy internal injuries by the cercarial furca in predatory rotifers, thus leading to high mortality of both groups of predators $(25-28 \%$ individuals in 5-6 h).

In contrast, cyclopoids (M. distinctus, M. viridis), which can tear the soft prey into pieces (Brandl, 1998), survived well when fed with cercariae. They reproduced (up to four 
offspring generations in 17 days) when maintained exclusively on cercarial diet ad libitum. The average interclutch periods of these cyclopoids ( 1 and 2 days for $M$. distinctus and $M$. viridis, respectively) on cercarial diet were similar to reported for these genera in food-rich conditions (Phong et al. 2008). In addition, the average number of $M$. viridis offsprings hatched from one clutch was higher in our experiments than in literature (Phong et al. 2008). Therefore, these results showed for the first time that cercariae can adequately satisfy dietary needs of their predators, e. g. cyclopoids. It is important to mention that feeding conditions in our experiments were similar to natural high-density cercarial "clouds" and intensities of predation on cercariae may be lower in the presence of alternative prey (Welsh et al. 2017). Therefore, additional experiments are needed to clarify whether zooplankters can consume cercariae selectively and detect cercarial "clouds" produced by infected snails in natural conditions.

The trophic links between cercariae and planktonic predators can be an important energy pathway from benthic organisms (mollusk hosts of trematodes) to zooplankton through parasites' free-living stages. It is now well established that inclusion of parasites in ecosystem models causes changes in food webs topology, e.g. increase the linkage density, food chain length, connectivity and nestedness (Hatcher et al. 2012). The valuable role of cercariae in benthic food webs has been assumed previously (Thieltges et al. 2008b; Morley, 2012), however their impact on the energy transfer in plankton has not been studied yet. Since the production of both planktonic crustaceans and trematode cercariae is often high in the nearshore zone of lakes and ponds (Shuter and Ing, 1997; Lacroix et al. 1999; Preston et al. 2013), trophic relationships between these organisms could significantly contribute to the energy flow in food webs, at least, in shallow lentic ecosystems.

Our data on species-specific effects of cercariae on survival and reproduction of their predators suggest that parasites can influence the structure of planktonic communities. For example, the diet composed of $D$. pseudospathaceum cercariae enhanced mortality in some zooplankters (e.g. Asplanchna rotifers) and facilitated reproduction in others (copepods $M$. distinctus, M. viridis) in our experiments. We suppose that similar effects may occur in natural communities, leading to parasite-induced alterations in the relative abundance of certain zooplankters and their prey (nano- and microplankton) and predators (e.g. fish larvae) through trophic cascades. Our observations on predatory rotifers Asplanchna spp. showed that many of the largest individuals died soon after they ingested cercariae, while the small Asplanchna were not observed consuming cercariae at all. Exposure of rotifers with cercariae 
led to a decrease of the largest size classes in the experimental group when compared with the control group ( $13 \%$ and $39 \%$ of total numbers respectively). Thus, high abundance of cercariae in water may also lead to changes in the size structure in populations of planktonic organisms. However, this effect may be insignificant when cercariae are less abundant and there are other prey available, because rotifers could avoid cercariae when having a food choice.

Another consequence of predation on infective stages of parasites is its negative effect on parasite transmission (Orlofske et al. 2012; Thieltges et al. 2008a). For example, aquatic cercaria-predators can remove a large share (up to 99\%) of trematodes' free-living larvae and reduce infection intensities in target hosts by 30-100\% (Christensen, 1979; Schotthoefer et al. 2007; Orlofske et al. 2012; Gopko et al. 2017a). Our study indicated that cyclopoids can consume a substantial amount of $D$. pseudospathaceum cercariae, therefore their importance in reduction of parasite transmission to fish hosts needs further investigation. Cyclopoids are common in coastal zones of lakes, where myriads of cercariae are produced by infected mollusks every day, therefore the removal of cercariae by these zooplankters could be substantial. We assume that in areas of high zooplankton densities fish may be more protected against infestation with cercariae.

Avoidance of parasites is an important factor structuring fish shoals and influencing fish habitat choice (Poulin and FitzGerald, 1989; Stumbo et al. 2012; Mikheev et al. 2013). Spatial distribution of small fish often correlates with high densities of zooplankton prey and is related to fish foraging needs, hydrography, etc. (George and Winfield, 2000; Höffle et al. 2013; Swalethorp et al. 2015). However, it is possible that fish aggregate with zooplankton also to avoid a parasitic threat. This assumption can be tested experimentally using nonplanktivorous fishes. For the parasite, a release of cercariae close to zooplankton aggregations, which are attractive for fishes, can lead to the trade-off between the benefit of enhanced transmission and the cost of predation by zooplankters. Although the influence of predators' presence in the environment on the cercariae release by a snail host is still unknown, the significant effect of chemical cues from the target host was previously shown (Mouritsen, 2002; Lagrue et al. 2016). Since trematodes have been reported to manipulate behaviour of their snail hosts in different ways, e.g. by changing morphology, habitat and feeding preferences of snails (Levri, 1999; Miura et al. 2006; Kamiya and Poulin, 2012), they possibly can also regulate the production of cercariae depending on the presence/absence of the cercaria-predators in the environment. 
Present results show ability of zooplankters to harvest cercariae and reproduce on a cercarial diet, supporting the view of important trophic interaction between zooplankton and parasite larvae. We assume that this can affect functioning of aquatic food webs via direct consumption of cercariae and via indirect consequences on survival, reproduction and behaviour of other hosts in parasites' life cycles (mollusks, fishes, birds). Further investigations are needed to test these assumptions and provide more information about the role of direct predation on parasite larvae in modifying the structure and functioning of freshwater ecosystems.

\section{SUPPLEMENTARY MATERIAL}

The supplementary material is available at Figshare data repository

\section{(https://figshare.com/s/b44fa55b0d78eabf9e65).}

\section{ACKNOWLEDGEMENTS}

We are very grateful to the technical staff of the Konnevesi research station (University of Jyväskylä, Finland) for their assistance.

\section{FINANCIAL SUPPORT}

The research was supported by the Academy of Finland (J. T., mobility grants 298911, 311033); the Ella and Georg Ehrnrooth Foundation (E. M. and M. G. mobility grants 2016 and 2017, respectively) and the Russian Foundation for Basic Research (V. M., grant 17-0400247).

\section{ETHICAL STANDARDS}

The authors assert that all procedures contributing to this work comply with the ethical standards of the relevant national and institutional guides on the care and use of laboratory animals. 


\section{CONFLICTS OF INTEREST}

None 


\section{REFERENCES}

Achinelly, MF, Micieli, MV and García, JJ (2003) Pre-parasitic juveniles of Strelkovimermis spiculatus Poinar and Camino, 1986 (Nematoda: Mermithidae) predated upon by freshwater copepods (Crustacea: Copepoda). Nematology 5, 885-888. doi: 10.1163/156854103773040790.

Amundsen, PA, Lafferty, KD, Knudsen, R, Primicerio, R, Klemetsen, A and Kuris, AM (2009) Food web topology and parasites in the pelagic zone of a subarctic lake. Journal of Animal Ecology 78, 563-572. doi: 10.1111/j.1365-2656.2008.01518.x.

Bernardi, R and Giussani, G (1990) Are blue-green algae a suitable food for zooplankton? An overview. Hydrobiologia 200/201, 29-41. doi: 10.1007/BF02530326.

Brandl, Z (1998) Feeding strategies of planktonic cyclopoids in lacustrine ecosystems. Journal of Marine Systems 15, 87-95. doi: 10.1016/S0924-7963(97)00042-0.

Buck, JC, Truong, L and Blaustein, AR (2011) Predation by zooplankton on Batrachochytrium dendrobatidis: biological control of the deadly amphibian chytrid fungus? Biodiversity and Conservation 20, 3549-3553. doi: 10.1007/s10531-011-0147-4.

Christensen, NO, Nansen, P and Frandsen, F (1977) Interference with Fasciola hepatica snail finding by various aquatic organisms. Parasitology 74, 285-290. doi: 10.1017/S0031182000047909.

Christensen, NO (1979) Schistosoma mansoni: interference with cercarial host-finding by various aquatic organisms. Journal of Helminthology 53, 7-14. doi: $10.1017 / \mathrm{S} 0022149 \mathrm{X} 00005678$.

Christensen, NO, Frandsen, F and Nansen, P (1980) The interaction of some 
environmental factors influencing Schistosoma mansoni cercarial host-finding. Journal of Helminthology 54, 203-205. doi: 10.1017/S0022149X0000660X.

Conover, RJ (1978) Transformation of organic matter. In Kinne (ed). Marine ecology, vol. 4, Dynamics. New York, USA: Wiley, pp. 221-499.

Cummins, KW, Costa, RR, Rowe, RE, Moshiri, GA, Scanlon, RM and Zajdel, RK (1969) Ecological energetics of a natural population of the predaceous zooplankter Leptodora kindtii Focke (Cladocera). Oikos 20, 189-223. doi: 10.2307/3543189.

Feltz, CJ and Miller, GE (1996) An asymptotic test for the equality of coefficients of variation from k populations. Statistics in Medicine 15, 647-658. doi: 10.1002/(SICI)10970258(19960330)15:6<647::AID-SIM184>3.0.CO;2-P.

Frost, BW (1972) Effects of size and concentration of food particles on the feedlng behavior of the marine planktonic copepod Calanus pacificus. Limnology Oceanography 17, 805-815. doi: 10.4319/1o.1972.17.6.0805.

George, DG and Winfield, IJ (2000) Factors influencing the spatial distribution of zooplankton and fish in Loch Ness, UK. Freshwater Biology 43, 557-570. doi:10.1046/j.1365-2427.2000.00539.x.

Gopko, M, Mikheev, VN and Taskinen, J (2015) Changes in host behaviour caused by immature larvae of the eye fluke: evidence supporting the predation suppression hypothesis. Behavioral Ecology and Sociobiology 69, 1723-1730. doi: 10.1007/s00265-015-1984-z.

Gopko, M*, Mironova, E*, Pasternak, A, Mikheev, V and Taskinen, J (2017a) Freshwater mussels (Anodonta anatina) reduce transmission of a common fish trematode (eye fluke Diplostomum pseudospathaceum). Parasitology 144, 1971-1979. doi: $10.1017 / \mathrm{S} 0031182017001421$.

Gopko, M, Mikheev, VN and Taskinen, J (2017b) Deterioration of basic components of the 
anti-predator behavior in fish harboring eye fluke larvae. Behavioral Ecology and Sociobiology 71, 68. doi: 10.1007/s00265-017-2300-x.

Haas, W, Granzer, M and Brockelman, CR (1990) Opisthorchis viverrini: finding and recognition of the fish host by the cercariae. Experimental Parasitology 71, 422-431. doi: $10.1016 / 0014-4894(90) 90068-\mathrm{N}$.

Haas, W (1992) Physiological analysis of cercarial behavior. The Journal of Parasitology 78, 243-255. doi:10.2307/3283471.

Hamilton, PT, Richardson, JML and Anholt, BR (2012) Daphnia in tadpole mesocosms: trophic links and interactions with Batrachochytrium dendrobatidis. Freshwater Biology 57, 676-683. doi: 10.1111/j.1365-2427.2011.02731.x.

Hatcher, MJ, Dick, JTA and Dunn, AM (2012) Diverse effects of parasites in ecosystems: linking interdependent processes. Frontiers in Ecology and the Environment 10, 186-194. doi: $10.1890 / 110016$.

Höffle, H, Nash, RDM, Falkenhaug, T and Munk, P (2013) Differences in vertical and horizontal distribution of fish larvae and zooplankton, related to hydrography. Marine Biology Research 9, 629-644. doi: 10.1080/17451000.2013.765576.

Hudson, PG, Dobson, AP, and Lafferty, KD (2006) Is a healthy ecosystem one that is rich in parasites? Trends in Ecology and Evolution 21, 381-385. doi: 10.1016/j.tree.2006.04.007.

Intapan, P, Kaewkes, S and Maleewong, W (1992) Control of Opisthorchis viverrini cercariae using the copepod Mesocyclops leuckarti. Southeast Asian Journal of Tropical Medical Public Health 23, 348-349.

Jasper, JT, Nguyen, MT, Jones, ZL, Ismail, NS, Sedlak, DL, Sharp, JO., Luthy, RG, Horne, AJ and Nelson, KL (2013) Unit process wetlands for removal of trace organic contaminants and pathogens from municipal wastewater effluents. Environmental 
Engineering Science 30, 421-436. doi: 10.1089/ees.2012.0239.

Johnson, PTJ, Dobson, A, Lafferty, KD, Marcogliese DJ, Orlofske, SA, Poulin, R and Thieltges, DW (2010) When parasites become prey: ecological and epidemiological significance of eating parasites. Trends in Ecology and Evolution 25, 362-371. doi: 10.1016/j.tree.2010.01.005.

Kamiya, T and Poulin, R (2012) Parasite-induced behavioural changes to the trade-off between foraging and predator evasion in a marine snail. Journal of Experimental Marine Biology and Ecology 438, 61-67. doi: 10.1016/j.jembe.2012.09.002.

Karvonen, A, Kirsi S, Hudson, PJ and Valtonen, ET (2004a) Patterns of cercarial production from Diplostomum spathaceum: terminal investment or bet hedging? Parasitology 129, 87-92. doi: 10.1017/S0031182004005281.

Karvonen, A, Seppälä, O and Valtonen, ET (2004b) Eye fluke-induced cataract formation in fish: quantitative analysis using an ophthalmological microscope. Parasitology 129, 473478. doi: $10.1017 / \mathrm{S} 0031182004006006$.

Karvonen, A, Savolainen, M, Seppälä, O and Valtonen, ET (2006) Dynamics of Diplostomum spathaceum infection in snail hosts at a fish farm. Parasitology Research 99, 341-345. doi: 10.1007/s00436-006-0137-8.

Kerfoot, WC (1977) Implications of copepod predation. Limnology and Oceanography 22, 316-325. doi: 10.4319/1o.1977.22.2.0316.

Koski, M, Breteler, WK. and Schogt, N (1998) Effect of food quality on rate of growth and development of the pelagic copepod Pseudocalanus elongatus (Copepoda, Calanoida). Marine Ecology Progress Series 170, 169-187. doi: 10.3354/meps170169.

Kuris, AM, Hechinger, RF, Shaw, JC, Whitney, KL, Aguirre-Macedo, L, Boch, CA, Dobson, AP, Dunham, EJ, Fredensborg, BL, Huspeni, TC, Lorda, J, Mababa, L, 
Mancini, FT, Mora, AB, Pickering, M, Talhouk, NL, Torchin, ME and Lafferty, KD (2008) Ecosystem energetic implications of parasite and free-living biomass in three estuaries. Nature 454, 515-518. doi: 10.1038/nature06970.

Lacroix, G, Lescher-Moutoue, F and Bertolo, A (1999) Biomass and production of plankton in shallow and deep lakes: are there general patterns? Annales de Limnologie 35, 111-122. doi: 10.1051/limn/1999016.

Lafferty, KD, Dobson, AP and Kuris, AM (2006) Parasites dominate food web links. Proceedings of the National Academy of Sciences 103,1121111216. doi:10.1073/pnas.0604755103.

Lafferty, KD, Allesina, S, Arim, M, Briggs, CJ, De Leo, G, Dobson, AP, Dunne, JA, Johnson, PTJ, Kuris, AM, Marcogliese, DJ, Martinez, ND, Memmott, J, Marquet, PA, McLaughlin, JP, Mordecai, EA, Pascual, M, Poulin, R and Thieltges, DW (2008) Parasites in food webs: the ultimate missing links. Ecology Letters 11, 533-546. doi: 10.1111/j.1461-0248.2008.01174.x.

Lagrue, C, Rinnevalli, R and Poulin, R (2017) Smelling the future: Subtle life-history adjustments in response to environmental conditions and perceived transmission opportunities in a trematode. Parasitology 144, 464-474. doi:10.1017/S003118201600192X.

Lasley-Rasher, RS, Nagel, K, Angra, A and Yen, J (2016) Intoxicated copepods: ingesting toxic phytoplankton leads to risky behaviour. Proceedings Biological Sciences 283, 20160176. doi: 10.1098/rspb.2016.0176.

Levri, EP (1999) Parasite-induced change in host behavior of a freshwater snail: parasitic manipulation or byproduct of infection? Behavioral Ecology 10, 234-241. doi: 10.1093/beheco/10.3.234.

Lyholt, HCK and Buchmann, K (1996) Diplostomum spathaceum: effects of temperature 
and light on cercarial shedding and infection of rainbow trout. Diseases of Aquatic Organisms 25, 169-173. doi: 10.3354/dao025169.

Marwick, B and Krishnamoorthy, K (2016) cvequality: Tests for the Equality of Coefficients of Variation from Multiple Groups. R package version 0.1.1. https:/CRAN.Rproject.org/package $=$ cvequality.

Marten, GG and Reid, JW (2007) Cyclopoid copepods. Journal of the American Mosquito Control Association 23, 65-92. doi: 10.2987/8756-971X(2007)23[65:CC]2.0.CO;2.

Mikheev, VN, Pasternak, AF, Taskinen, J and Valtonen, ET (2010) Parasite-induced aggression and impaired contest ability in a fish host. Parasites and Vectors 3, 17. doi: $10.1186 / 1756-3305-3-17$.

Mikheev, VN, Pasternak, AF, Taskinen, J and Valtonen, TE (2013) Grouping facilitates avoidance of parasites by fish. Parasites and Vectors 6, 301. doi: 10.1186/1756-3305-6-301. Miura, O, Kuris, AM, Torchin, ME, Hechinger, RF and Chiba, S (2006) Parasites alter host phenotype and may create a new ecological niche for snail hosts. Proceedings of the Royal Society of London B 273, 1323-1328. doi: 10.1098/rspb.2005.3451.

Morley, N (2012) Cercariae (Platyhelminthes: Trematoda) as neglected components of zooplankton communities in freshwater habitats. Hydrobiologia 691, 7-19. doi: $10.1007 / \mathrm{s} 10750-012-1029-9$.

Mouritsen, KN (2002) The Hydrobia ulvae-Maritrema subdolum association: influence of temperature, salinity, light, water-pressure and secondary host exudates on cercarial emergence and longevity. Journal of Helminthology 76, 341-347. doi: 10.1079/JOH2002136.

Orlofske, SA, Jadin, RC, Preston, DL and Johnson, PTJ (2012) Parasite transmission in complex communities: predators and alternative hosts alter pathogenic infections in amphibians. Ecology 93, 1247-1253. doi: 10.1890/11-1901.1. 
Orlofske, SA, Jadin, RC and Johnson, PTJ (2015) It's a predator-eat-parasite world: how characteristics of predator, parasite and environment affect consumption. Oecologia 178, 537-547. doi: 10.1007/s00442-015-3243-4.

Owen, SF, Barber, I and Hart, PJB (1993) Low level infection by eye fluke, Diplostomum spp., affects the vision of three-spined sticklebacks, Gasterosteus aculeatus. Journal of Fish Biology 42, 803-806. doi: 10.1111/j.1095-8649.1993.tb00387.x.

Phong, TV, Nabuko, T, Histohi, K and Takagi, M (2008) Comparative evaluation of fecundity and survivorship of six copepod (Copepoda: Cyclopoidae) species in relation to selection of candidates biological control agents against Aedes aegypti. Journal of the American Mosquito Control Association 24, 61-69. doi: 10.2987/5672.1

Poulin, R and FitzGerald, GJ (1989a) Risk of parasitism and microhabitat selection in juvenile sticklebacks. Canadian Journal of Zoology 67, 14-18. doi: 10.1139/z89-003.

Poulin, R and FitzGerald, GJ (1989b). Shoaling as an anti-ectoparasite mechanism in juvenile sticklebacks (Gasterosteus spp.). Behavioral Ecology and Sociobiology 24, 251-255. doi: 10.1007/BF00295205.

Preston, DL, Orlofske, SA, Lambden, JP and Johnson, PTJ (2013) Biomass and productivity of trematode parasites in pond ecosystems. Journal of Animal Ecology 82, 509517. doi: 10.1111/1365-2656.12030.

R Core Team (2017) R: A language and environment for statistical computing. R Foundation for Statistical Computing, Vienna, Austria. https://www.R-project.org/.

Schmeller, DS, Blooi, M, Martel, A, Garner, TWJ, Fisher, MC, Azemar, F, Clare, FC, Leclerc, C, Jäger, L, Guevara-Nieto, M, Loyau, A and Pasmans, F (2014) Microscopic aquatic predators strongly affect infection dynamics of a globally emerged pathogen. Current Biology 24, 176-180. doi: 10.1016/j.cub.2013.11.032. 
Schotthoefer, AM, Labak, KM and Beasley, VR (2007) Ribeiroia ondatrae cercariae are consumed by aquatic invertebrate predators. Journal of Parasitology 93, 1240-1243. doi: 10.1645/GE1129R.1.

Seppälä, O, Karvonen, A and Valtonen, ET (2004). Parasite-induced change in host behaviour and susceptibility to predation in an eye fluke-fish interaction. Animal Behavior 68, 257-263. doi: 10.1016/j.anbehav.2003.10.021.

Shigin, A (1980) Trematodes of the genus Diplostomurn in biocoenoses of the trout farm "Skhodnya". Trudy Gel' mintologicheskoi Laboratorii Gel' minty zhivotnykh i rastenii 30, 140-202. (in Russian)

Shuter, BJ and Ing, KK (1997) Factors affecting the production of zooplankton in lakes. Canadian Journal of Fisheries and Aquatic Sciences 54, 359-377. doi: 10.1139/f96270.

StatSoft, Inc. (2011) STATISTICA (data analysis software system), version 10. Tulsa, OK, USA. Retrieved from http://www.statsoft.com/.

Stumbo, AD, James, CT, Goater, CP and Wisenden, BD (2012) Shoaling as an antiparasite defence in minnows (Pimephales promelas) exposed to trematode cercariae. Journal of Animal Ecology 81, 1319-1326. doi: 10.1111/j.1365-2656.2012.02012.x.

Swalethorp, R, Malanski, E, Agersted, MD, Nielsen, TG and Munk, P (2015) Structuring of zooplankton and fish larvae assemblages in a freshwater-influenced Greenlandic fjord: influence from hydrography and prey availability. Journal of Plankton Research, 37, 102119. doi: 10.1093/plankt/fbu099.

Taskinen, J (1998) Cercarial production of the trematode Rhipidocotyle fennica in clams kept in the field. Journal of Parasitology 84, 345-349. doi: 10.2307/3284493. 
Thieltges, DW, Jensen, KT and Poulin, R (2008a) The role of biotic factors in the transmission of free-living endohelminth stages. Parasitology 135, 407-426. doi: 10.1017/S0031182007000248.

Thieltges, DW, de Montaudouin, X, Fredensborg, B, Jensen, KT, Koprivnikar, J and Poulin, R (2008b) Production of marine trematode cercariae: a potentially overlooked path of energy flow in benthic systems. Marine Ecology Progress Series 372, 147-155. doi: 10.3354/meps07703.

Tokobaev, MM, Kutikova, LA and Chibichenko, NT (1979) The predatory rotifer, Eosphora ehrenbergi, a biological eliminator of cercariae in lake Issyk-Kul'. Trudy Gel' mintologicheskoi Laboratorii Gel' minty zhivotnykh i rastenii 29, 146-149. (in Russian)

Turner, JT (2014) Planktonic marine copepods and harmful algae. Harmful Algae 32, 81-93. doi: 10.1016/j.hal.2013.12.001.

Valtonen, ET and Gibson, DI (1997) Aspects of the biology of diplostomid metacercarial (Digenea) populations occurring in fishes in different localities of northern Finland. Annales Zoologici Fennici 34, 47-59.

Welsh, JE, Liddell, C, Van Der Meer, J and Thieltges, DW (2017) Parasites as prey: the effect of cercarial density and alternative prey on consumption of cercariae by four non-host species. Parasitology 144, 1775-1782. doi: 10.1017/S0031182017001056.

Wickham, H (2009) ggplot2: elegant graphics for data analysis. Springer-Verlag, New York,USA. 


\section{TABLES}

Table 1. The design and results of incubation experiments with planktonic predators feeding on D. pseudospathaceum cercariae. Mean sizes of zooplankters, their numbers per beaker (N, ind./120-125 mL), mean concentration of cercariae (cercariae $\left.\mathrm{mL}^{-1} \pm \mathrm{SD}\right)$ in the control and predation treatments at the start and end of experiment ( $\mathrm{C}$ start, $\mathrm{C}$ final) and incubation times for each experiment are presented. There were 5 control (without zooplankters) and 5 predation treatment replicates in all experiments, except of the exp. 6 with Asplanchna spp. (3 predation replicates). Predation effect was studied as a change in cercariae number in control vs. predation treatment at the beginning and the end of the experiment (effect of time*treatment interaction). More detailed data are presented in the Supplementary Table S1.

\begin{tabular}{|c|c|c|c|c|c|c|c|c|c|}
\hline \multirow[t]{2}{*}{ Exp. } & \multirow[t]{2}{*}{ Predators } & \multirow{2}{*}{$\begin{array}{l}\text { Mean sizes of predators } \\
( \pm \mathrm{SD}, \mu \mathrm{m})^{\dagger}\end{array}$} & \multirow{2}{*}{$\begin{array}{l}\mathrm{N} \\
\text { (ind.) }\end{array}$} & \multirow{2}{*}{$\begin{array}{l}\text { Time } \\
\text { (h) }\end{array}$} & \multicolumn{2}{|c|}{ Control treatment } & \multicolumn{2}{|c|}{ Predation treatment } & \multirow[t]{2}{*}{ Predation effect $t^{\|}$} \\
\hline & & & & & C start & $\mathrm{C}$ final & C start & C final & \\
\hline 1 & Calanoids Arctodiaptomus & $993 \pm 43$ & 10 & 2 & $24 \pm 2$ & $23 \pm 2$ & $28 \pm 3$ & $22 \pm 4$ & $n s$ \\
\hline \multirow{2}{*}{2} & \multirow[t]{2}{*}{ paulseni } & \multirow[t]{2}{*}{$964 \pm 40$} & \multirow[t]{2}{*}{18} & $2^{\ddagger}$ & \multirow[t]{2}{*}{$6 \pm 1$} & $6 \pm 1$ & \multirow[t]{2}{*}{$6 \pm 0.3$} & $4 \pm 1$ & \multirow[t]{2}{*}{$F_{1,8}=7.172 \mathrm{~h}$} \\
\hline & & & & 5 & & $6 \pm 1$ & & $4 \pm 1$ & \\
\hline \multirow[t]{2}{*}{3} & \multirow{4}{*}{$\begin{array}{l}\text { Cyclopoids } \\
\text { Macrocyclops distinctus } \\
\text { and Megacyclops viridis }\end{array}$} & \multirow{2}{*}{$\begin{array}{l}1132 \pm 70 \text { and } 1258 \pm 139 \\
\text { respectively }\end{array}$} & \multirow[t]{2}{*}{10} & 2 & \multirow[t]{2}{*}{$24 \pm 2$} & $23 \pm 2$ & \multirow[t]{2}{*}{$23 \pm 2$} & \multirow[t]{2}{*}{$17 \pm 2$} & \multirow[t]{2}{*}{$P=0.009, \quad F_{1,8}=11.74$} \\
\hline & & & & & & & & & \\
\hline \multirow[t]{2}{*}{4} & & \multirow{2}{*}{$\begin{array}{l}1094 \pm 57 \text { and } 1285 \pm 130 \\
\text { respectively }\end{array}$} & \multirow[t]{2}{*}{16} & 2 & \multirow[t]{2}{*}{$12 \pm 2$} & $11 \pm 1$ & \multirow[t]{2}{*}{$11 \pm 1$} & $4 \pm 1$ & \multirow[t]{2}{*}{$P<0.001, F_{2,16}=26.44$} \\
\hline & & & & 5 & & $12 \pm 1$ & & $2 \pm 1$ & \\
\hline 5 & Cladocerans & $2391 \pm 201$ & $18-19$ & 5 & $10 \pm 1$ & $11 \pm 1$ & $12 \pm 0.3$ & $5 \pm 3$ & $P=0.002, \quad F_{1,7}=24.87$ \\
\hline
\end{tabular}


6 no measurements

$1255 \pm 281$
40

5

$\begin{array}{lllll}5 & 17 \pm 1 & 18 \pm 1 & 18 \pm 1 & 17 \pm 2\end{array}$

$12 \pm 1.8 \quad 10 \pm 2$

$P=0.009, \quad F_{1,6}=14.48$

Rotifers Asplanchna spp.

$18 \pm 1+17 \pm 2$

ns

† copepod prosome lengths and cladoceran body lengths were measured after fixation; rotifer body lengths (in the stretched state) were measured in vivo.

$\ddagger$ cercariae were counted also after the first two hours of 5-h incubation.

results of repeated-measures ANOVA. ns - nonsignificant effect $(P>0.05)$ of time*treatment interaction. 


\section{FIGURE LEGENDS}

Fig. 1. The rotifer Asplanchna priodonta with ingested D. pseudospathaceum cercariae inside its body, which are indicated by arrows $(\mathbf{C}$ - recently ingested, DC - partially digested, without furca).

Fig. 2. Reproductive characteristics of females of two cyclopoid species, fed exclusively with $D$. pseudospathaceum cercariae ad libitum during 17 days. The longevity ${ }^{\S}$ (h) of reproductive periods and the offspring numbers (nauplii) hatched from the each egg clutch ${ }^{\text {I }}$ are shown. Clutch period is the period when female carries egg clutch until hatching of nauplii, interclutch - the period between two clutches. The "box" represents the interquartile range (IQR) of the reproductive characteristics within groups with median (black line). Whiskers extend from the highest to lowest values within $1.5 * \mathrm{IQR}$. Suspected outliers, i.e. all observations lying outside $1.5 * \mathrm{IQR}$, are shown as dots. More detailed data are presented in the Supplementary Table S2.

$\dagger$ - data for 18 females (clutches I, II), 14 females (clutch III), 7 females (clutch IV).

$\$$ - data for 11 females (clutches I, II), 9 females (clutch III), 5 females (clutch IV).

$\S$ - the longevity of periods may be overestimated since we monitored the reproductive status of females twice a day.

I - the nauplii hatched from the first clutch were not counted since their numbers could be more strongly affected by the female feeding before the experiment than by experimental feeding conditions (cercarial diet). 


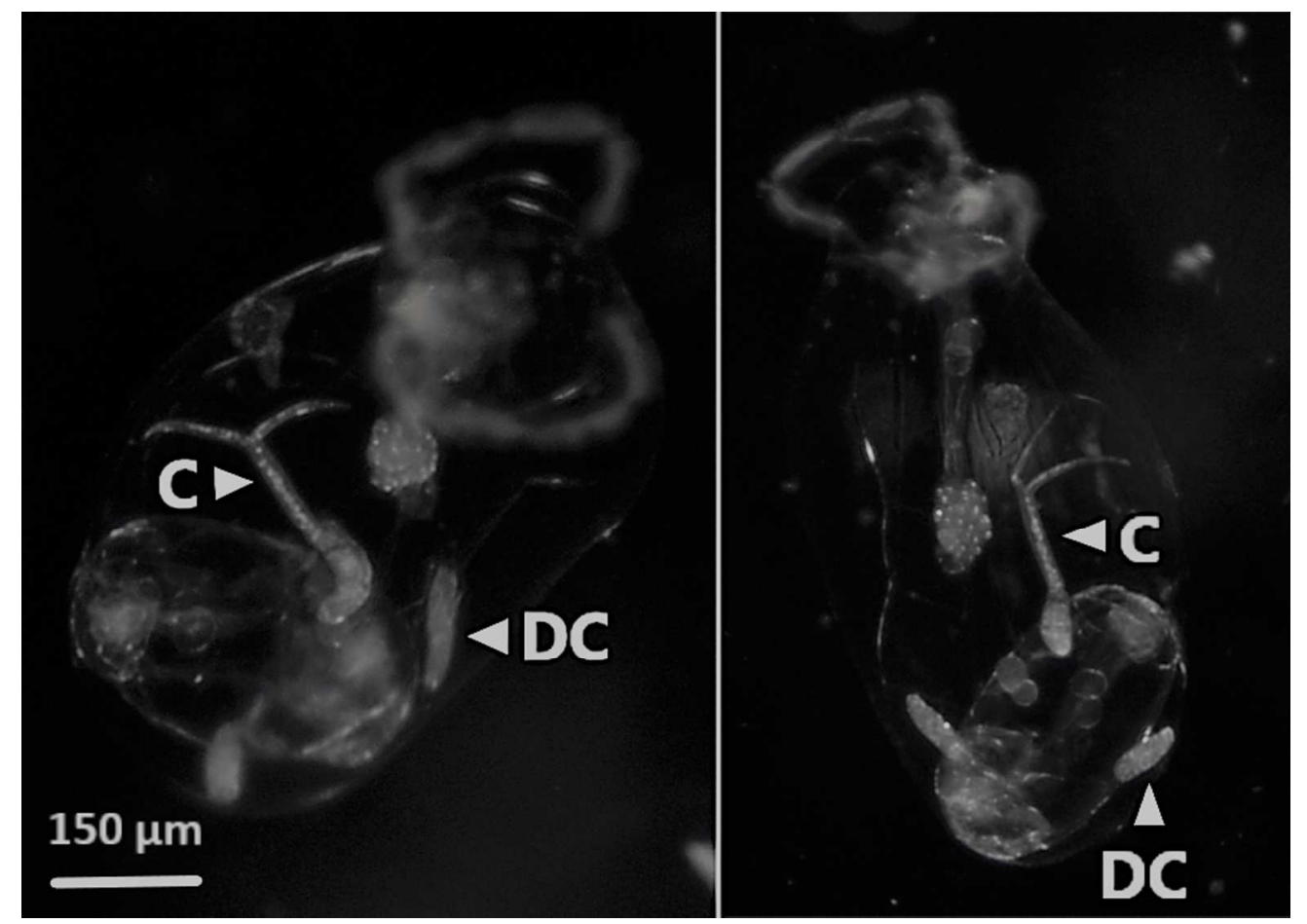

Fig. 1. The rotifer Asplanchna priodonta with ingested $D$. pseudospathaceum cercariae inside its body, which are indicated by arrows (C - recently ingested, DC - partially digested, without furca).

$80 \times 57 \mathrm{~mm}(300 \times 300$ DPI $)$ 


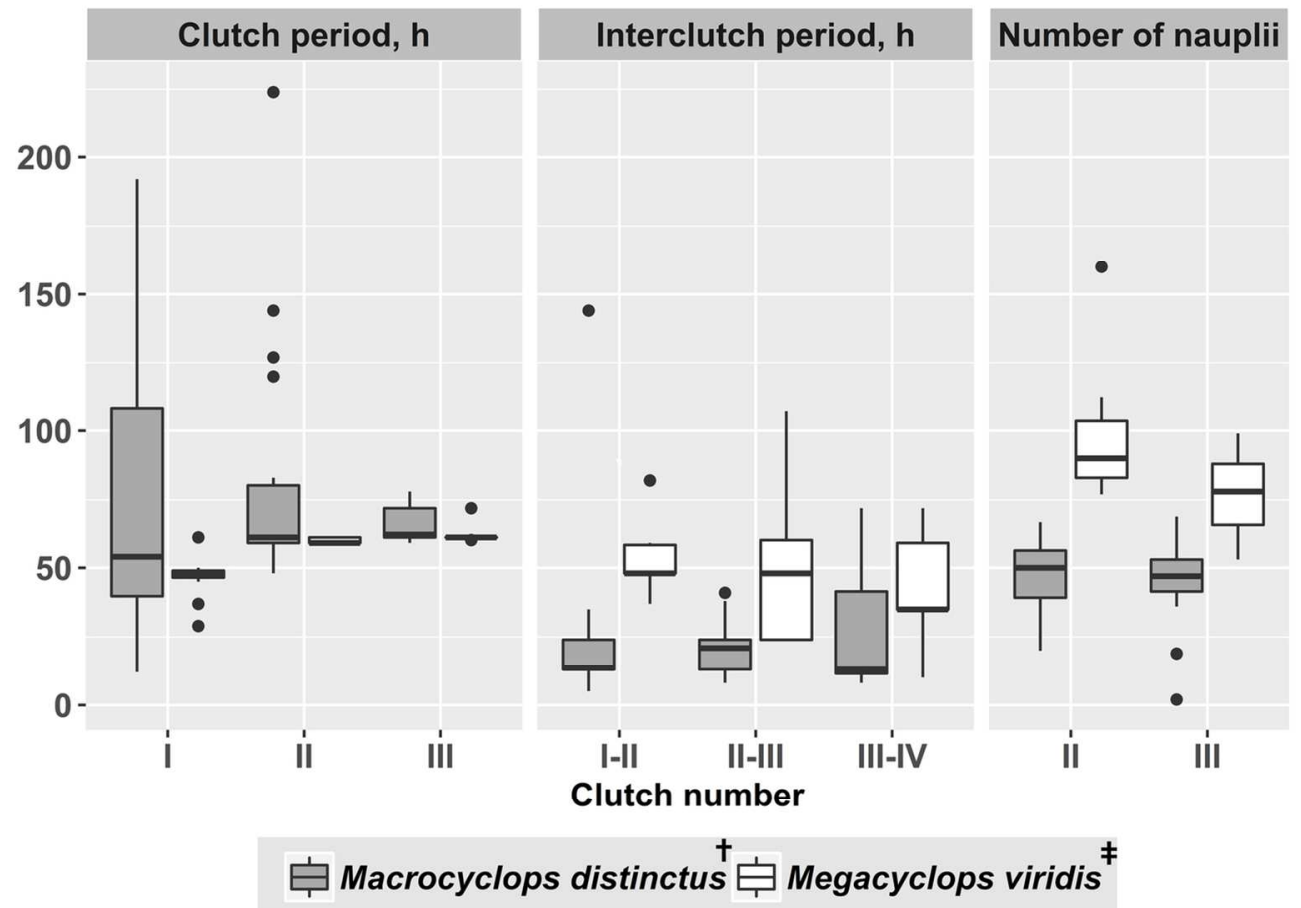

Fig. 2. Reproductive characteristics of females of two cyclopoid species, fed exclusively with $D$. pseudospathaceum cercariae ad libitum during 17 days. The longevity ${ }^{\S}(\mathrm{h})$ of reproductive periods and the offspring numbers (nauplii) hatched from the each egg clutch" are shown. Clutch period is the period when female carries egg clutch until hatching of nauplii, interclutch - the period between two clutches. The "box" represents the interquartile range (IQR) of the reproductive characteristics within groups with median (black

line). Whiskers extend from the highest to lowest values within $1.5 *$ IQR. Suspected outliers, i.e. all observations lying outside $1.5 * \mathrm{IQR}$, are shown as dots. More detailed data are presented in the Supplementary Table S2.!! + + - data for 18 females (clutches I, II), 14 females (clutch III), 7 females (clutch IV). !! + $\neq$ - data for 11 females (clutches I, II), 9 females (clutch III), 5 females (clutch IV).!! + $\S$ the longevity of periods may be overestimated since we monitored the reproductive status of females twice a day.!! + ๆ - the nauplii hatched from the first clutch were not counted since their numbers could be more strongly affected by the female feeding before the experiment than by experimental feeding conditions (cercarial diet). !!

$119 \times 86 \mathrm{~mm}(300 \times 300$ DPI) 
Supplementary table S1. Feeding experiments with different zooplankters and cercariae of Diplostomı

\begin{tabular}{|c|c|c|c|c|c|c|c|}
\hline \multirow[b]{2}{*}{ Experimen glass $\mathrm{N}$} & \multicolumn{4}{|c|}{ Concentration of cercariae (cercal } & \multicolumn{3}{|c|}{ Number of predators, } \\
\hline & Treatment & Start & Final $1(2 \mathrm{r}$ & Final $2(5 \mathrm{r}$ & r volu Initial & & \\
\hline 1 & 1 Arctodiaptc & 28.5 & 18.165 & & 120 & 10 & 10 \\
\hline 1 & 2 Arctodiaptc & 29.835 & 17.5 & & 120 & 10 & 10 \\
\hline 1 & 3 Arctodiaptc & 24 & 23.335 & & 120 & 10 & 10 \\
\hline 1 & 4 Arctodiaptc & 31.835 & 23.5 & & 120 & 10 & 10 \\
\hline 1 & 5 Arctodiaptc & 24.665 & 25.5 & & 120 & 10 & 10 \\
\hline 1 & 1 Control & 25.665 & 24.5 & & 120 & 0 & 0 \\
\hline 1 & 2 Control & 22.835 & 19.5 & & 120 & 0 & 0 \\
\hline 1 & 3 Control & 27.335 & 23.835 & & 120 & 0 & 0 \\
\hline 1 & 4 Control & 23.5 & 23. & & 120 & 0 & 0 \\
\hline 1 & 5 Control & 22.835 & 25 & & 120 & 0 & 0 \\
\hline 2 & 1 Arctodiaptc & 6 & 4.666667 & 1.666667 & 125 & 18 & 18 \\
\hline 2 & 2 Arctodiaptc & 6.166667 & 2.833333 & 4 & 125 & 18 & 18 \\
\hline 2 & 3 Arctodiaptc & 6.333333 & 4.666667 & 2.666667 & 125 & 18 & 18 \\
\hline 2 & 4 Arctodiaptc & 6 & 5.5 & 5 & 125 & 18 & 16 \\
\hline 2 & 5 Arctodiaptc & 6.833333 & 4.166667 & 4.333333 & 125 & 18 & 18 \\
\hline 2 & 1 control & 5.666667 & 6.666667 & 6.166667 & 125 & 0 & 0 \\
\hline 2 & 2 control & 6.666667 & 5.333333 & 3.666667 & 125 & 0 & 0 \\
\hline 2 & 3 control & 7.5 & 6.666667 & 5 & 125 & 0 & 0 \\
\hline 2 & 4 control & 4.25 & 4.166667 & 6.833333 & 125 & 0 & 0 \\
\hline 2 & 5 control & 4.75 & 5.333333 & 6.333333 & 125 & 0 & 0 \\
\hline 3 & 1 Cyclopoids & 25.66667 & 17.66667. & & 120 & 10 & 10 \\
\hline 3 & 2 Cyclopoids & 25.5 & 15.66667. & & 120 & 10 & 10 \\
\hline 3 & 3 Cyclopoids & 20.5 & 17.33333 & & 120 & 10 & 9 \\
\hline 3 & 4 Cyclopoids & 20.83333 & 14.66667 & & 120 & 10 & 10 \\
\hline 3 & 5 Cyclopoids & 23.33333 & 17.83333 & & 120 & 10 & 10 \\
\hline 3 & 1 Control & 25.665 & 24.5 & & 120 & 0 & 0 \\
\hline 3 & 2 Control & 22.835 & 19.5 & & 120 & 0 & 0 \\
\hline 3 & 3 Control & 27.335 & 23.835 & & 120 & 0 & 0 \\
\hline 3 & 4 Control & 23.5 & 23 & & 120 & 0 & 0 \\
\hline 3 & 5 Control & 22.835 & 25 & & 120 & 0 & 0 \\
\hline 4 & 1 Cyclopoids & 11.5 & 5.5 & 2.666667 & 120 & 16 & 15 \\
\hline 4 & 2 Cyclopoids & 10 & 4.5 & 3.833333 & 120 & 16 & 15 \\
\hline 4 & 3 Cyclopoids & 13.33333 & 5.333333 & 1.5 & 120 & 16 & 16 \\
\hline 4 & 4 Cyclopoids & 10.66667 & 3 & 1 & 120 & 16 & 16 \\
\hline 4 & 5 Cyclopoids & 9.833333 & 3 & 2 & 120 & 16 & 16 \\
\hline 4 & 1 control & 10.875 & 11.5 & 11.66667 & 120 & 0 & 0 \\
\hline 4 & 2 control & 9.375 & 12.83333 & 12.66667 & 120 & 0 & 0 \\
\hline 4 & 3 control & 14.5 & 10.83333 & 12 & 120 & 0 & 0 \\
\hline 4 & 4 control & 11.83333 & 9.666667 & 10.5 & 120 & 0 & 0 \\
\hline 4 & 5 control & 14 & 11.5 & 12.5 & 120 & 0 & 0 \\
\hline 5 & 1 Sida crysta & 11.66667 & & 8.833333 & 120 & 19 & 9 \\
\hline 5 & 2 Sida crysta & $11.33333-$ & & 5.166667 & 120 & 19 & 14 \\
\hline 5 & 3 Sida crysta & $12-$ & & 1.666667 & 120 & 19 & 15 \\
\hline 5 & 4 Sida crysta & $11.33333-$ & & 3.833333 & 120 & 18 & 13 \\
\hline 5 & $5^{*}$ Sida crysta & $10.16667-$ & & 10.83333 & 120 & 18 & 3 \\
\hline 5 & 1 control & $8.5-$ & & 10.5 & 120 & 0 & 0 \\
\hline 5 & 2 control & $10-$ & & 10.8 & 120 & 0 & 0 \\
\hline 5 & 3 control & $11-$ & & 11.66667 & 120 & 0 & 0 \\
\hline 5 & 4 control & 11.16667 - & & 11.16667 & 120 & 0 & 0 \\
\hline 5 & 5 control & 11.16667 & & 10.5 & 120 & 0 & 0 \\
\hline 6 & 1 Asplanchn: & : $10.83333-$ & & 7.333333 & 120 & $40 r$ & \\
\hline 6 & 2 Asplanchn: & : 13.83333 & & 12 & 120 & $40 r$ & \\
\hline
\end{tabular}




$\begin{array}{lr}3 \text { Asplanchn: } & 10.66667 \text { - } \\ 1 \text { control } & 8.5- \\ 2 \text { control } & 10- \\ 3 \text { control } & 11 \text { - } \\ 4 \text { control } & 11.16667- \\ 5 \text { control } & 11.16667- \\ 1 \text { Asplanchn: } & 17.5- \\ 2 \text { Asplanchn: } & 19- \\ 3 \text { Asplanchn: } & 19.33333- \\ 4 \text { Asplanchn: } & 17- \\ 5 \text { Asplanchn: } & 18.5- \\ 1 \text { control } & 17.66667- \\ 2 \text { control } & 17- \\ 3 \text { control } & 18.33333- \\ 4 \text { control } & 17- \\ 5 \text { control } & 15.83333-\end{array}$

$\begin{array}{rr}9.166667 & 120 \\ 10.5 & 120 \\ 10.8 & 120 \\ 11.66667 & 120 \\ 11.16667 & 120 \\ 10.5 & 120 \\ 18.16667 & 125 \\ 14.16667 & 125 \\ 15.83333 & 125 \\ 19.33333 & 125 \\ 17 & 125 \\ 20.16667 & 125 \\ 16.16667 & 125 \\ 17.83333 & 125 \\ 18.5 & 125 \\ 18.16667 & 125\end{array}$

$\begin{array}{cc}40 \text { no data } \\ 0 & 0 \\ 0 & 0 \\ 0 & 0 \\ 0 & 0 \\ 0 & 0 \\ 35 & 24 \\ 35 & 29 \\ 35 & 24 \\ 35 & 26 \\ 35 & 23 \\ 0 & 0 \\ 0 & 0 \\ 0 & 0 \\ 0 & 0 \\ 0 & 0\end{array}$

*was excluded from the analysis, because of high mortality of predators ( $>80 \%$ individuals c 
ım pseudospathaceum 
died 
Supplementary table S2. Reproductive characteristics of females of two cyclopoid species, fed exclus * - the nauplii hatched from the first clutch were not counted since their numbers could be more strongly

\begin{tabular}{|c|c|c|c|c|c|}
\hline Cyclopoid $₫ F$ & № & peri Se & clutch & Female № & er of Sequence \\
\hline Macrocyclc & 1 & 192 I & Macrocyclc & 1 & 67 II \\
\hline Macrocyclc & 2 & $61 \mathrm{I}$ & Macrocyclc & 2 & 50 II \\
\hline Macrocyclc & 3 & 48 I & Macrocyclc & 3 & 47 II \\
\hline Macrocyclc & 4 & $120 \mathrm{I}$ & Macrocyclc & 4 & 38 II \\
\hline Macrocyclc & 5 & $120 \mathrm{I}$ & Macrocyclc & 5 & 37 II \\
\hline Macrocyclc & 6 & $125 \mathrm{I}$ & Macrocyclc & 6 & 50 II \\
\hline Macrocyclc & 7 & 12 I & Macrocyclc & 7 & $54 \mathrm{II}$ \\
\hline Macrocyclc & 8 & 48 I & Macrocyclc & 8 & $61 \mathrm{II}$ \\
\hline Macrocyclc & 9 & $34 \mathrm{I}$ & Macrocyclc & 9 & 54 II \\
\hline Macrocyclc & 10 & $48 \mathrm{I}$ & Macrocyclc & 10 & $47 \mathrm{II}$ \\
\hline Macrocyclc & 11 & 72 I & Macrocyclc & 11 & 38 II \\
\hline Macrocyclc & 12 & 132 I & Macrocyclc & 12 & 59 II \\
\hline Macrocyclc & 13 & $60 \mathrm{I}$ & Macrocyclc & 13 & $43 \mathrm{II}$ \\
\hline Macrocyclc & 14 & $48 \mathrm{I}$ & Macrocyclc & 14 & $57 \mathrm{II}$ \\
\hline Macrocyclc & 15 & 131 & Macrocyclc & 15 & 29 II \\
\hline Macrocyclc & 16 & 37 I & Macrocyclc & 16 & $51 \mathrm{II}$ \\
\hline Macrocyclc & 17 & $37 \mathrm{I}$ & Macrocyclc & 17 & $60 \mathrm{II}$ \\
\hline Macrocyclc & 18 & $61 \mathrm{I}$ & Macrocyclc & 18 & $20 \mathrm{II}$ \\
\hline Macrocyclc & 1 & 66 II & Macrocyclc & 1 & $53 \mathrm{III}$ \\
\hline Macrocyclc & 2 & 53 II & Macrocyclc & 2 & $54 \mathrm{III}$ \\
\hline Macrocyclc & 3 & 48 II & Macrocyclc & 3 & $47 \mathrm{III}$ \\
\hline Macrocyclc & 4 & 59 II & Macrocyclc & 7 & $43 \mathrm{III}$ \\
\hline Macrocyclc & 5 & $60 \mathrm{II}$ & Macrocyclc & 8 & $69 \mathrm{III}$ \\
\hline Macrocyclc & 6 & 61 II & Macrocyclc & 9 & $43 \mathrm{III}$ \\
\hline Macrocyclc & 7 & 127 II & Macrocyclc & 10 & $19 \mathrm{III}$ \\
\hline Macrocyclc & 8 & 48 II & Macrocyclc & 11 & $47 \mathrm{III}$ \\
\hline Macrocyclc & 9 & 72 II & Macrocyclc & 12 & $53 \mathrm{III}$ \\
\hline Macrocyclc & 10 & 120 II & Macrocyclc & 13 & $42 \mathrm{III}$ \\
\hline Macrocyclc & 11 & 59 II & Macrocyclc & 14 & $41 \mathrm{III}$ \\
\hline Macrocyclc & 12 & 59 II & Macrocyclc & 15 & $53 \mathrm{III}$ \\
\hline Macrocyclc & 13 & 67 II & Macrocyclc & 16 & $2 \mathrm{III}$ \\
\hline Macrocyclc & 14 & 224 II & Macrocyclc & 17 & $53 \mathrm{III}$ \\
\hline Macrocyclc & 15 & 144 II & Macrocyclc & 18 & $36 \mathrm{III}$ \\
\hline Macrocyclc & 16 & 83 II & Megacyclo| & 19 & 84 II \\
\hline Macrocyclc & 17 & 58 II & Megacyclo| & 20 & 82 II \\
\hline Macrocyclc & 18 & 61 II & Megacyclo| & 21 & $85 \mathrm{II}$ \\
\hline Macrocyclc & 2 & $61 \mathrm{III}$ & Megacyclo| & 22 & 106 II \\
\hline Macrocyclc & 7 & 72 III & Megacyclo| & 23 & 90 II \\
\hline Macrocyclc & 8 & $69 \mathrm{III}$ & Megacyclo| & 24 & $80 \mathrm{II}$ \\
\hline Macrocyclc & 9 & $59 \mathrm{III}$ & Megacyclo| & 25 & 77 II \\
\hline Macrocyclc & 10 & 72 III & Megacyclo| & 26 & 112 II \\
\hline Macrocyclc & 11 & $61 \mathrm{III}$ & Megacyclo| & 27 & $101 \mathrm{II}$ \\
\hline Macrocyclc & 13 & $59 \mathrm{III}$ & Megacyclo| & 28 & 92 II \\
\hline Macrocyclc & 15 & $78 \mathrm{III}$ & Megacyclo| & 29 & 160 II \\
\hline Macrocyclc & 18 & 62 III & Megacyclo| & 20 & $66 \mathrm{III}$ \\
\hline Megacyclo| & 19 & 37 I & Megacyclo| & 22 & $53 \mathrm{III}$ \\
\hline Megacyclo| & 20 & 48 I & Megacyclo| & 23 & $98 \mathrm{III}$ \\
\hline Megacyclo| & 21 & $48 \mathrm{I}$ & Megacyclo| & 24 & $78 \mathrm{III}$ \\
\hline Megacyclo| & 22 & $50 \mathrm{I}$ & Megacyclo| & 25 & $99 \mathrm{III}$ \\
\hline Megacyclo| & 23 & $48 \mathrm{I}$ & Megacyclo| & 26 & $78 \mathrm{III}$ \\
\hline Megacyclo| & 24 & 29 I & Megacyclo| & 27 & $88 \mathrm{III}$ \\
\hline Megacyclo| & 25 & $50 \mathrm{I}$ & Megacyclo| & 28 & $82 \mathrm{III}$ \\
\hline
\end{tabular}




$\begin{array}{lll}\text { Megacyclo| } & 26 & 48 \mathrm{I} \\ \text { Megacyclo| } & 27 & 45 \mathrm{I} \\ \text { Megacyclo| } & 28 & 61 \mathrm{I} \\ \text { Megacyclo| } & 29 & 48 \mathrm{I} \\ \text { Megacyclo| } & 20 & 61 \mathrm{II} \\ \text { Megacyclo| } & 22 & 59 \mathrm{II} \\ \text { Megacyclo| } & 23 & 61 \mathrm{II} \\ \text { Megacyclo| } & 24 & 59 \mathrm{II} \\ \text { Megacyclo| } & 25 & 59 \mathrm{II} \\ \text { Megacyclo| } & 26 & 61 \mathrm{II} \\ \text { Megacyclo| } & 27 & 61 \mathrm{II} \\ \text { Megacyclo| } & 28 & 59 \mathrm{II} \\ \text { Megacyclo| } & 29 & 59 \mathrm{II} \\ \text { Megacyclo| } & 22 & 61 \mathrm{III} \\ \text { Megacyclo| } & 23 & 61 \mathrm{III} \\ \text { Megacyclo| } & 24 & 60 \mathrm{III} \\ \text { Megacyclo| } & 25 & 61 \mathrm{III} \\ \text { Megacyclo| } & 26 & 61 \mathrm{III} \\ \text { Megacyclo| } & 27 & 72 \mathrm{III}\end{array}$


ively with Diplostomum pseudospathaceum cercariae ad libitum during 17 days. The longevity (h) of re I affected by the female feeding before the experiment than by experimental feeding conditions (cercaric

\begin{tabular}{|c|c|c|c|c|c|}
\hline number of clutch & Female № & Iutch Sequ & f clutches & Female № & egg \\
\hline Macrocyclc & 1 & $13 \mathrm{I}-\mathrm{II}$ & Macrocyclc & 1 & 205 \\
\hline Macrocyclc & 2 & $11 \mathrm{I}-\mathrm{II}$ & Macrocyclc & 2 & 72 \\
\hline Macrocyclc & 3 & $24 \mathrm{I}-\mathrm{II}$ & Macrocyclc & 3 & 72 \\
\hline Macrocyclc & 4 & $13 \mathrm{I}-\mathrm{II}$ & Macrocyclc & 4 & 133 \\
\hline Macrocyclc & 5 & $13 \mathrm{I}-\mathrm{II}$ & Macrocyclc & 5 & 133 \\
\hline Macrocyclc & 6 & $19 \mathrm{I-II}$ & Macrocyclc & 6 & 144 \\
\hline Macrocyclc & 7 & $12 \mathrm{I}-\mathrm{II}$ & Macrocyclc & 7 & 24 \\
\hline Macrocyclc & 8 & $24 \mathrm{I}-\mathrm{II}$ & Macrocyclc & 8 & 72 \\
\hline Macrocyclc & 9 & $14 \mathrm{I}-\mathrm{II}$ & Macrocyclc & 9 & 48 \\
\hline Macrocyclc & 10 & $24 \mathrm{I}-\mathrm{II}$ & Macrocyclc & 10 & 72 \\
\hline Macrocyclc & 11 & $13 \mathrm{I}-\mathrm{II}$ & Macrocyclc & 11 & 85 \\
\hline Macrocyclc & 12 & $13 \mathrm{I}-\mathrm{II}$ & Macrocyclc & 12 & 145 \\
\hline Macrocyclc & 13 & $5 \mathrm{I}-\mathrm{II}$ & Macrocyclc & 13 & 65 \\
\hline Macrocyclc & 14 & 29 I-II & Macrocyclc & 14 & 77 \\
\hline Macrocyclc & 15 & $35 \mathrm{I-II}$ & Macrocyclc & 15 & 48 \\
\hline Macrocyclc & 16 & 144 I-II & Macrocyclc & 16 & 181 \\
\hline Macrocyclc & 17 & $35 \mathrm{I-II}$ & Macrocyclc & 17 & 72 \\
\hline Macrocyclc & 18 & $11 \mathrm{I}-\mathrm{II}$ & Macrocyclc & 18 & 72 \\
\hline Macrocyclc & 1 & 41 II-III & Macrocyclc & 1 & 107 \\
\hline Macrocyclc & 2 & 19 II-III & Macrocyclc & 2 & 72 \\
\hline Macrocyclc & 3 & 13 II-III & Macrocyclc & 3 & 61 \\
\hline Macrocyclc & 4 & 24 II-III & Macrocyclc & 4 & 83 \\
\hline Macrocyclc & 5 & 24 II-III & Macrocyclc & 5 & 84 \\
\hline Macrocyclc & 6 & 24 II-III & Macrocyclc & 6 & 85 \\
\hline Macrocyclc & 7 & 17 II-III & Macrocyclc & 7 & 144 \\
\hline Macrocyclc & 8 & 13 II-III & Macrocyclc & 8 & 61 \\
\hline Macrocyclc & 9 & 13 II-III & Macrocyclc & 9 & 85 \\
\hline Macrocyclc & 10 & 13 II-III & Macrocyclc & 10 & 133 \\
\hline Macrocyclc & 11 & 24 II-III & Macrocyclc & 11 & 83 \\
\hline Macrocyclc & 12 & 24 II-III & Macrocyclc & 12 & 83 \\
\hline Macrocyclc & 13 & 13 II-III & Macrocyclc & 13 & 80 \\
\hline Macrocyclc & 14 & 35 II-III & Macrocyclc & 14 & 259 \\
\hline Macrocyclc & 15 & 8 II-III & Macrocyclc & 15 & 152 \\
\hline Macrocyclc & 17 & 38 II-III & Macrocyclc & 18 & 82 \\
\hline Macrocyclc & 18 & 21 II-III & Macrocyclc & 7 & 80 \\
\hline Macrocyclc & 7 & 8 III-IV & Macrocyclc & 8 & 93 \\
\hline Macrocyclc & 8 & 24 III-IV & Macrocyclc & 9 & 72 \\
\hline Macrocyclc & 9 & 13 III-IV & Macrocyclc & 10 & 83 \\
\hline Macrocyclc & 10 & 11 III-IV & Macrocyclc & 11 & 120 \\
\hline Macrocyclc & 11 & 59 III-IV & Macrocyclc & 13 & 131 \\
\hline Macrocyclc & 13 & 72 III-IV & Macrocyclc & 18 & 74 \\
\hline Macrocyclc & 18 & 12 III-IV & Megacyclo| & 20 & 96 \\
\hline Megacyclo| & 20 & $48 \mathrm{I}-\mathrm{II}$ & Megacyclo| & 21 & 130 \\
\hline Megacyclo| & 21 & $82 \mathrm{I-II}$ & Megacyclo & 22 & 109 \\
\hline Megacyclo| & 22 & 59 I-II & Megacyclo| & 23 & 96 \\
\hline Megacyclo| & 23 & $48 \mathrm{I}-\mathrm{II}$ & Megacyclo & 24 & 85 \\
\hline Megacyclo| & 24 & $56 \mathrm{I}-\mathrm{II}$ & Megacyclo| & 25 & 109 \\
\hline Megacyclo| & 25 & 59 I-II & Megacyclo & 26 & 96 \\
\hline Megacyclo| & 26 & $48 \mathrm{I}-\mathrm{II}$ & Megacyclo & 27 & 83 \\
\hline Megacyclo| & 27 & $38 \mathrm{I}-\mathrm{II}$ & Megacyclo & 28 & 109 \\
\hline Megacyclo| & 28 & 48 I-II & Megacyclo & 29 & 85 \\
\hline Megacyclo| & 29 & $37 \mathrm{I}-\mathrm{II}$ & Megacyclo & 20 & 72 \\
\hline
\end{tabular}




$\begin{array}{rrrrrr}\text { Megacyclo| } & 20 & 107 \text { II-III } & \text { Megacyclo| } & 22 & 83 \\ \text { Megacyclo| } & 22 & 24 \text { II-III } & \text { Megacyclo| } & 23 & 144 \\ \text { Megacyclo| } & 23 & 83 \text { II-III } & \text { Megacyclo| } & 24 & 119 \\ \text { Megacyclo| } & 24 & 60 \text { II-III } & \text { Megacyclo| } & 25 & 83 \\ \text { Megacyclo| } & 25 & 24 \text { II-III } & \text { Megacyclo| } & 26 & 120 \\ \text { Megacyclo| } & 26 & 59 \text { II-III } & \text { Megacyclo| } & 27 & 96 \\ \text { Megacyclo| } & 27 & 35 \text { II-III } & \text { Megacyclo| } & 28 & 107 \\ \text { Megacyclo| } & 28 & 48 \text { II-III } & \text { Megacyclo| } & 29 & 83 \\ \text { Megacyclo| } & 29 & 24 \text { II-III } & \text { Megacyclo| } & 22 & 96 \\ \text { Megacyclo| } & 22 & 35 \text { III-IV } & \text { Megacyclo| } & 23 & 120 \\ \text { Megacyclo| } & 23 & 59 \text { III-IV } & \text { Megacyclo| } & 24 & 132 \\ \text { Megacyclo| } & 24 & 72 \text { III-IV } & \text { Megacyclo| } & 25 & 96 \\ \text { Megacyclo| } & 25 & 35 \text { III-IV } & \text { Megacyclo| } & 27 & 82 \\ \text { Megacyclo| } & 27 & 10 \text { III-IV } & & & \end{array}$


productive periods and the offspring numbers (nauplii) hatched from the each egg clutch* are shown. \l diet).

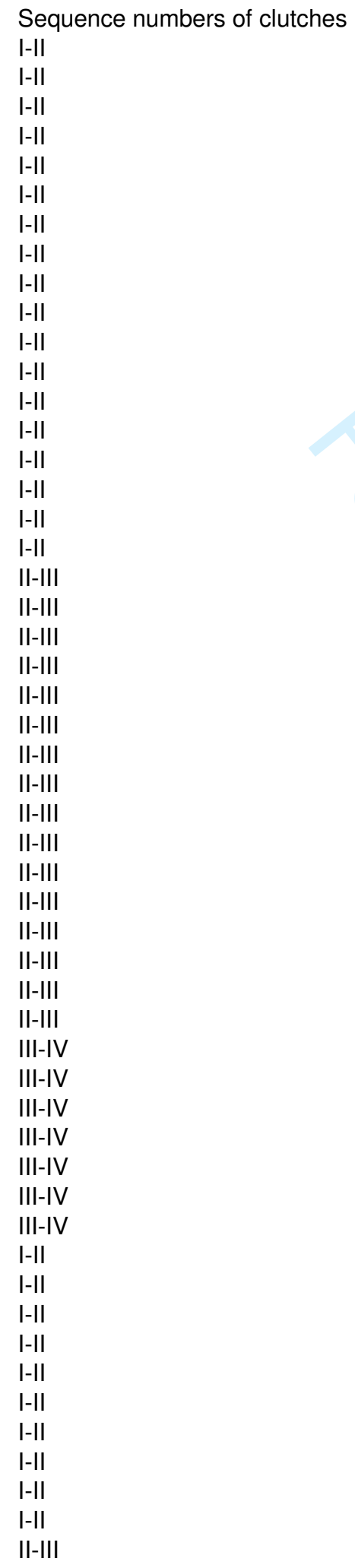


II-III

II-III

II-III

II-III

II-III

II-III

II-III

II-III

III-IV

III-IV

III-IV

III-IV

III-IV 